Journal of

(c) All rights are reserved by Tallman $\mathrm{R}$, et al.

\title{
Pyodermatitis-Pyostomatitis Vegetans: A Cutaneous Clue for Crohn's Disease
}

Keywords: Pyodermatitis-pyostomatitis vegetans; Crohn's disease; Inflammatory bowel disease

\begin{abstract}
Pyodermatitis-pyostomatitis vegetans is a neutrophilic dermatosis that is classically associated with inflammatory bowel disease. It is rare with less than 40 cases reported in the literature within the last 10 years. We discuss the case of a 30-year-old male who presented with pyodermatitis-pyostomatitis vegetans and previously undiagnosed Crohn's disease. We aim to emphasize the importance of promp recognition of pyodermatitis-pyostomatitis vegetans order to commence a thorough investigation of underlying inflammatory bowel disease, and initiate appropriate therapy. Because no standardized treatment regimens have been established, we also describe the variability in treatment responses seen with pyodermatitis-pyostomatitis vegetans with a review of the literature.
\end{abstract}

\section{Abbreviations}

Pyodermatitis-pyostomatitis vegetans (PPV); Inflammatory bowel disease (IBD); Non-steroidal anti-inflammatory (NSAID); Direct immunofluorescence (DIF); Gastrointestinal (GI); Ulcerative colitis (UC)

\section{Introduction}

Pyodermatitis-pyostomatitis vegetans (PPV) is a neutrophilic dermatosis characteristically associated with underlying inflammatory bowel syndrome (IBD) [1]. The first reported case of PPV was in 1898 by Francois Hallopeau [2], and only 37 cases of PPV were reported in the literature between 1979 and 2011 [3]. Diagnosis can be challenging due to its resemblance to autoimmune blistering disorders such as pemphigus vegetans, and infectious etiologies such as Staphylococcus aureus and blastomycosis. Recognizing the signs and symptoms of PPV is critical in order to prompt further work up for IBD and begin appropriate management, especially considering that responses to treatments can be variable among patients and often require trial and error to maintain remission. Here, we report a case of PPV that highlights the importance of prompt diagnosis, especially in cases where underlying IBD has yet to be uncovered. We also perform a literature review of treatment responses in patients with PPV.

\section{Case Presentation}

A 30-year-old Caucasian male with fever, hypotension, and tachycardia was admitted for one-week history of abdominal pain, diarrhea, rash, and concern for sepsis. Past medical history revealed another recent admission for melena, diarrhea, and abdominal pain which he had self-managed with 1 gram of ibuprofen per day. At that time, EGD and colonoscopy revealed edematous and ulcerated tissue with mucopurulent material. Biopsy revealed ulceration and granulation tissue, which was diagnosed as non-steroidal anti-inflammatory drug (NSAID)-induced colitis. NSAIDs were discontinued, however diarrhea and melena had since persisted.

\section{Clinical \& Investigative} Dermatology

Tallman $\mathbf{R}^{1 *}$, Beatty $\mathbf{C}^{1}$, Ghareeb $\mathrm{E}^{1}$, Gayam $\mathbf{S}^{2}$ and Zinn $\mathbf{Z}^{2}$ ${ }^{\prime}$ Department of Dermatology, West Virginia University Medicine, USA ${ }^{2}$ Department of Gastroenterology and Hepatology, West Virginia University Medicine, USA

\section{*Address for Correspondence}

Tallman R, Department of Dermatology, West Virginia University Medicine, Morgantown, Medical Center Drive, HSC P.O. Box 9158, Morgantown, WV 26506-9158, Fax: 304-293-8055, Tel: 855-988-273; Email: rmtallman@mix. wvu.edu

Submission: 30 July, 2021

Accepted: 06 September, 2021

Published: 10 September, 2021

Copyright: (c) 2021 Tallman R, et al. This is an open access article distributed under the Creative Commons Attribution License, which permits unrestricted use, distribution, and reproduction in any medium, provided the original work is properly cited.

Additional past medical history included intravenous drug abuse managed with buprenorphine and naloxone, and recent unintentional 35 -pound weight loss.

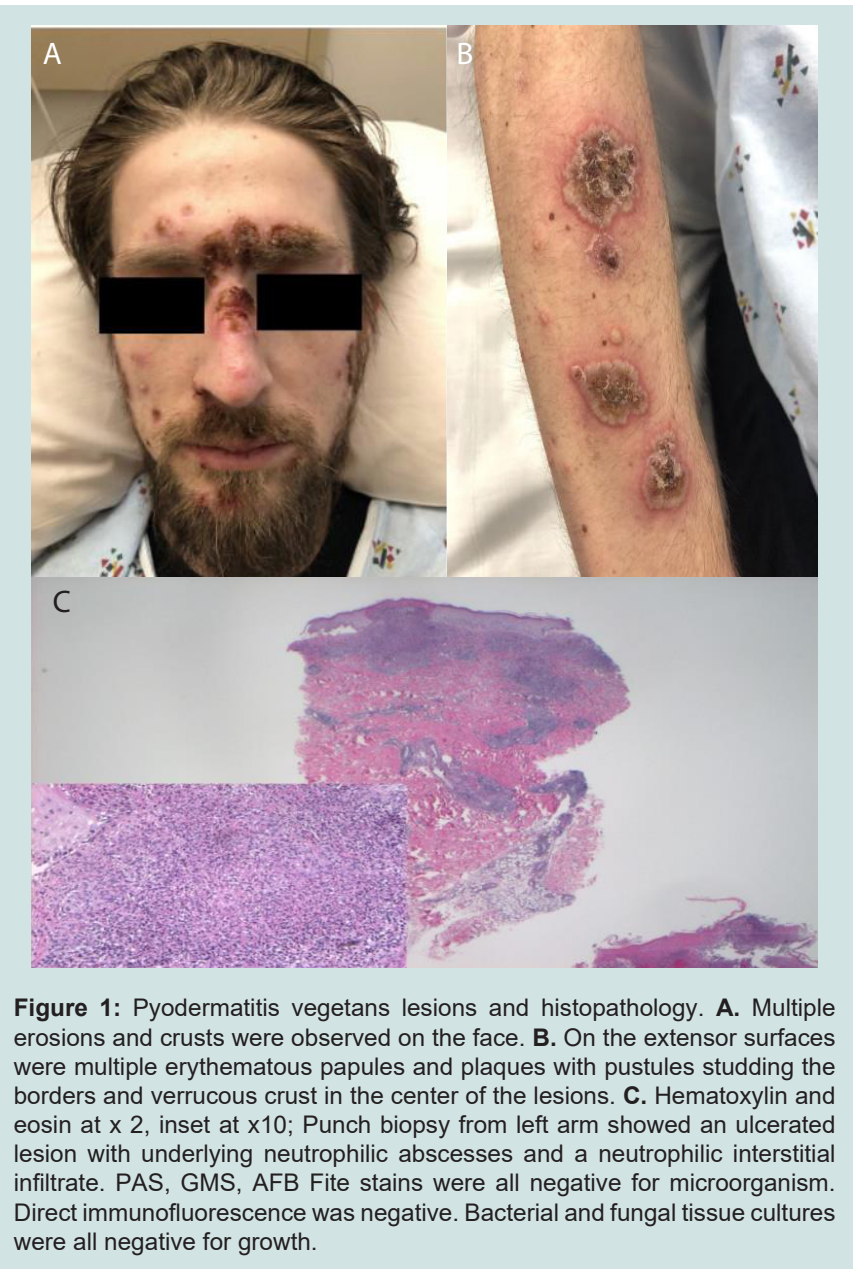


Citation: Tallman R, Beatty C, Ghareeb E, Gayam S, Zinn Z. Pyodermatitis-Pyostomatitis Vegetans: A Cutaneous Clue for Crohn's Disease. J Clin Investigat Dermatol. 2021;9(2): 4

ISSN: 2373-1044

Table 1: Pyodermatitis-pyostomatitis vegetans case reports since 2015.

\begin{tabular}{|c|c|c|c|}
\hline Author & Demographics & Presentation & Treatment and Response \\
\hline Gara et al. 2020 [2] & Male, 20s & $\begin{array}{l}\text { PPV of lips, buccal, and nasal mucosa } 6 \\
\text { years after Crohn's disease onset }\end{array}$ & Improvement with systemic corticosteroids with dose of $1 \mathrm{mg} / \mathrm{kg} / \mathrm{d}$ \\
\hline Gheisari et al. 2020 [3] & Female, 32 & $\begin{array}{l}\text { PPV of scalp, back, and lower abdomen } \\
\text { after a 16-year history of well-controlled } \\
\text { Crohn's disease on mesalamine and } \\
\text { azathioprine } 150 \mathrm{mg} \text { daily }\end{array}$ & $\begin{array}{l}\text { Failed ciprofloxacin and cephalexin; cleared with clobetasol } 0.05 \% \text { lotion daily } \\
\text { for scalp, clobetasol ointment twice daily for trunk, and dapsone } 25 \mathrm{mg} \text { daily }\end{array}$ \\
\hline $\begin{array}{l}\text { Tharwat \& Eltoraby } \\
2020[6]\end{array}$ & Male, 32 & $\begin{array}{l}\text { PPV of face and oral mucosa associated } \\
\text { with simultaneous autoimmune hepatitis }\end{array}$ & Cleared with prednisolone $1 \mathrm{mg} / \mathrm{kg} / \mathrm{d}$ for 4 weeks \\
\hline Li et al. 2020 [7] & Male, 25 & $\begin{array}{l}\text { PPV of oral mucosa, groin, } \\
\text { and penis without history of } \\
\text { IBD }\end{array}$ & $\begin{array}{l}\text { Cleared with prednisone } 25-40 \mathrm{mg} \text { daily; flared when tapered; cleared with } \\
\text { sulfasalazine } 500 \mathrm{mg} \text { daily reduced to } 250 \mathrm{mg} \text { daily after } 3 \text { months }\end{array}$ \\
\hline Alfurayh et al. 2019 [8] & Male, 35 & $\begin{array}{l}\text { PPV of trunk, axillae, inguinal folds, } \\
\text { and lower limbs after a 13-year history } \\
\text { of Crohn's status post colectomy for } \\
\text { refractory disease }\end{array}$ & $\begin{array}{l}\text { Cleared with clindamycin and rifampin } 300 \mathrm{mg} \text { twice daily each; had } \\
\text { recurrence } 3 \text { months later that cleared with prednisone } 0.5 \mathrm{mg} / \mathrm{kg} / \mathrm{d} \text { followed } \\
\text { by prednisone } 10 \mathrm{mg} \text { daily }\end{array}$ \\
\hline Bertlich et al. 2019 [9] & Female, 51 & $\begin{array}{l}\text { PPV of scalp, intertriginous areas, } \\
\text { and chest plus a 5-year history of } \\
\text { uncontrolled UC }\end{array}$ & $\begin{array}{c}\text { Failed } 2 \text { months of azathioprine } 150 \mathrm{mg} \text { daily, prednisolone } 80 \mathrm{mg} \text { daily, } \\
\text { and topical betamethasone cream; failed prednisolone } 150 \mathrm{mg} \text { daily plus } \\
\text { azathioprine } 200 \mathrm{mg} \text { daily plus topical mometasone cream; cleared with } \\
\text { infliximab } 5 \mathrm{mg} / \mathrm{kg} \text { every } 4 \text { weeks plus prednisolone } 30 \mathrm{mg} \text { daily tapered to } 5 \\
\text { mg daily plus topical mometasone }\end{array}$ \\
\hline Dodd et al. 2017 [4] & Female, 30s & $\begin{array}{l}\text { PPV with history of Crohn's and primary } \\
\text { sclerosing cholangitis }\end{array}$ & $\begin{array}{c}\text { Failed azathioprine, budesonide, adalimumab; Crohns responded to infliximab } \\
5 \mathrm{mg} / \mathrm{kg} \text { every } 6 \text { weeks; skin lesions cleared with intralesional triamcinolone } \\
10 \mathrm{mg} / \mathrm{mL} \text { injection plus dapsone } 100 \mathrm{mg} \text { daily }\end{array}$ \\
\hline $\begin{array}{l}\text { Kawahira et al. } 2017 \\
{[10]}\end{array}$ & Male, 64 & PPV with IBD excluded via colonoscopy & Cleared with 1 month of prednisolone $30 \mathrm{mg}$ daily \\
\hline $\begin{array}{l}\text { Carvalho et al. } 2016 \\
{[11]}\end{array}$ & Female, 79 & PPV of vulva without history of IBD & $\begin{array}{l}\text { Cleared with amoxicillin/clavulanic acid } 875 \mathrm{mg} / 125 \mathrm{mg} \text { twice daily for } 2 \text { weeks } \\
\text { plus prednisolone } 0.5 \mathrm{mg} / \mathrm{kg} / \mathrm{d} \text { tapered over } 1 \text { month }\end{array}$ \\
\hline $\begin{array}{l}\text { Uzuncakmak et al. } \\
\qquad 2015[12]\end{array}$ & Male, 16 & $\begin{array}{l}\text { PPV with 4-year history of UC } 7 \\
\text { months status post total colectomy and } \\
\text { discontinuation of corticosteroids }\end{array}$ & $\begin{array}{c}\text { Cleared with } 1 \text { month of methylprednisolone } 40 \mathrm{mg} \text { daily plus topical } \\
\text { mupirocin }\end{array}$ \\
\hline $\begin{array}{l}\text { Stingeni et al. } 2015 \\
\text { [13] }\end{array}$ & Male, 17 & PPV with active UC & $\begin{array}{l}\text { Cleared with prednisone } 1 \mathrm{mg} / \mathrm{kg} / \mathrm{d} ; \mathrm{Gl} \text { symptoms returned after tapering but } \\
\text { cleared with azathioprine } 125 \mathrm{mg} \text { plus mesalamine } 4800 \mathrm{mg} \text { daily }\end{array}$ \\
\hline Kim et al. 2015 [1] & Male, 27 & $\begin{array}{l}\text { PPV with 2-year history of Crohn's } \\
\text { disease treated with mesalamine and } \\
\text { azathioprine }\end{array}$ & $\begin{array}{c}\text { Cleared with prednisolone } 20 \mathrm{mg} \text { daily, dapsone, and colchicine with low dose } \\
\text { prednisolone plus dapsone required for maintenance }\end{array}$ \\
\hline
\end{tabular}
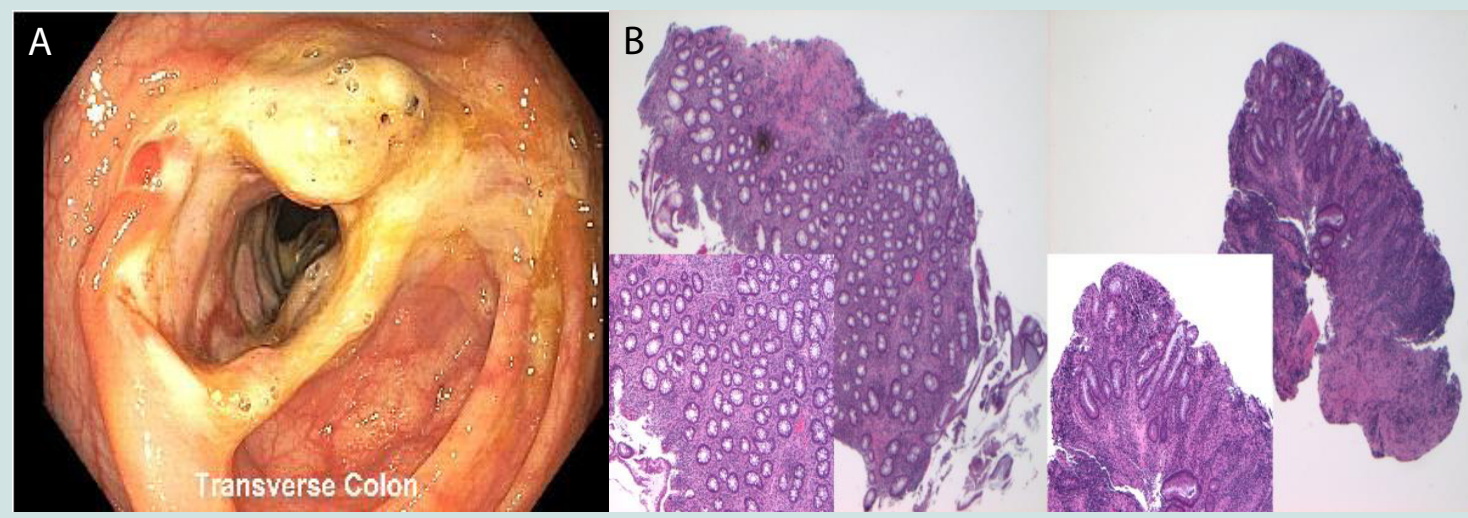

Figure 2: Inflammatory bowel disease. A. Colonoscopy revealed large ulcers found at the cecum, in the ascending colon, transverse colon, descending colon, and sigmoid colon. There was narrowing of the mucosa at several sites throughout the colon located near the ulcerations. B. Hematoxylin and eosin at $x 4$ insets at $\mathrm{x} 10 ;$ On histology, there was focal active colitis with ulceration and granulation tissue. No granulomas were seen.

On admission, he was noted to have an elevated white blood cell count of 12,800 /UL with $87 \%$ polymorphonuclear lymphocytes. C-Reactive Protein was elevated at $189.5 \mathrm{mg} / \mathrm{L}$ (normal $<8 \mathrm{mg} / \mathrm{L}$ ). Due to concern for sepsis secondary due to bacterial endocarditis, vancomycin, cefepime, and metronidazole were started. Examination of the rash revealed crusted vegetative plaques with a rim of pustules localized to the face, arms, and legs (Figures $1 \mathrm{~A}$ and $1 \mathrm{~B}$ ), and multiple erosions on the hard palate. Dermatologic differential diagnosis included deep fungal infection including blastomycosis, staphylococcal infection, pemphigus vegetans, and PPV. Biopsyrevealed necrotic epidermis, ulcerations, and neutrophilic infiltration (Figure 1C) with negative direct immunofluorescence (DIF). Tissue cultures were negative. Histologic diagnosis was compatible with a neutrophilic dermatosis including PPV. 
Citation: Tallman R, Beatty C, Ghareeb E, Gayam S, Zinn Z. Pyodermatitis-Pyostomatitis Vegetans: A Cutaneous Clue for Crohn's Disease. J Clin Investigat Dermatol. 2021;9(2): 4

\section{ISSN: 2373-1044}

Given ongoing diarrhea, melena, and skin biopsy compatible with PPV, gastroenterology was consulted. Colonoscopy revealed multiple strictures and large ulcers throughout the colon (Figure 2A). Biopsy of the colonic lesions revealed focal chronic active colitis with ulceration and granulation and no granulomas present (Figure 2B). IBD panel was consistent with Crohn's disease. Given his history and skin biopsy results, it was suspected that the lesions were PPV secondary to IBD. The patient was started on prednisone $40 \mathrm{mg}$ daily with significant improvement of skin and gastrointestinal (GI) symptoms. Vedolizumab infusions successfully controlled GI symptoms after prednisone was tapered, however cutaneous manifestations of PPV recurred. He was eventually switched to infliximab with successful remission of both Crohn's disease and PPV.

\section{Discussion}

PPV is a rare neutrophilic dermatosis that characteristically presents with friable pustules of the oral cavity that form a "snailtrack" pattern and papulopustular cutaneous lesions that give rise to vegetating plaques [1]. PPV has a well-documented association with IBD. Although it presents more often as a sequela of ulcerative colitis (UC), it can be seen in Crohn's disease as well, as in our patient [4] Cases have also been reported with primary sclerosing cholangitis. It is more common for patients to present with GI symptoms prior to the onset of PPV, however skin lesions may appear first in approximately $15 \%$ of cases [1]. Although classic PPV involves both the mouth and the skin, involvement of both sites is not required to render a diagnosis. The etiology of PPV remains uncertain, and males between the ages of 20 and 50 are preferentially affected (3:1 male: female ratio) [5].

PPV has characteristic histology including intraepithelial and subepithelial splitting with neutrophilic and eosinophilic microabscesses. It is important to distinguish PPV from auto-immune blistering disorders, including the pemphigus vegetans subtype of pemphigus vulgaris, IgA pemphigus, epidermolysis bullosa acquisita and dermatitis herpetiformis. Unlike these blistering disorders, DIF is negative in PPV. Additional considerations include cutaneous infections such as blastomycosis-like pyoderma due to S.aureus, and endemic dimorphic fungal infections such as blastomycosis, which can be differentiated by positive tissue cultures. Finally, clinical findings of oral ulcers and documented IBD also support the diagnosis of PPV [1,3]. Our patient exhibited characteristic histology of PPV with negative DIF, negative bacterial and fungal tissue cultures, and presence of oral ulcers diffusely on the hard palate with new diagnosis of underlying IBD.

There is no standardized treatment for PPV, and responses to different therapies are extremely variable among patients. To illustrate this, we performed a review of case reports and case series of PPV since 2015 in PubMed detailing patient responses to varying treatment regimens, which is summarized in Table 1. Although there is no standard algorithm for management, corticosteroids are considered efficacious first line therapy. They are used as systemic, intralesional, and topical treatments depending on disease severity. All the cases reviewed that used corticosteroids achieved clearance, however relapse was common when tapering [1-4,6-13]. Other systemic treatments for PPV include dapsone, azithromycin, cyclosporine, methotrexate, and infliximab, although varying efficacy has been reported with these options. Other topical treatments include tacrolimus, mupirocin, and antiseptic mouth washes for oral involvement.

Often the clinical courses of PPV and IBD are parallel [1], and successful management of the underlying IBD typically results in resolution of PPV [2]. However, there have also been cases in which PPV develops and persists despite well controlled IBD [1,3,4]. Our patient was started on vedolizumab initially for Crohn's disease due to preference over infliximab, however he was eventually switched to infliximab after his skin manifestations continued to flare. Both his skin and GI symptoms have been well controlled with infliximab infusions. Previous reports have shown successful responses of both cutaneous and GI symptoms to infliximab [14], whereas vedolizumab has shown less efficacy in treating cutaneous manifestations of IBD [15].

\section{Conclusions}

In summary, we present a case of PPV that posed a diagnostic challenge, given both the patient's risk factors for infectious cause and unknown underlying Crohn's disease. Our case demonstrates characteristic clinical and histological features of PPV and highlights the necessity to recognize this condition to screen for underlying IBD. A review of the literature revealed the majority of cases clear with corticosteroid treatment, however relapse is common once discontinued. Although PPV has been shown to resolve with management of IBD, this was inconsistent among the reviewed cases and with our patient as well. Responses to other treatments for maintenance of PPV is variable and often requires trial and error to achieve remission.

\section{References}

1. Kim TH, Kim SC (2015) Pyodermatitis-Pyostomatitis Vegetans Associated with Crohn's Disease. Ann Dermatol 27: 624-625.

2. Gara S, Souissi A, Mokni M (2020) Pyodermatitis Pyostomatitis Vegetans. JAMA Dermatol1 56: 335.

3. Gheisari M, Zerehpoosh FB, Zaresharifi S (2020) Pyodermatitis-pyostomatitis vegetans: a case report and review of literature. Dermatol Online 26: 13030.

4. Dodd EM, Howard JR, Dulaney ED, Rosenthal SI, Wanna MR, et al. (2017) Pyodermatitis-pyostomatitis vegetans associated with asymptomatic inflammatory bowel disease. Int J Dermatol 56: 1457-1459.

5. Ficarra G, Baroni G, Massi D (2010) Pyostomatitis vegetans: cellular immune profile and expression of IL-6, IL-8 and TNF-alpha. Head Neck Pathol 4: 1-9.

6. Tharwat S, Eltoraby EE (2020) Pyodermatitis-pyostomatitis vegetans associated with autoimmune hepatitis:unreported co-existence. Gastroenterol Hepatol Bed Bench13: 188-190.

7. Li S, Li Z, Feng S (2020) Low-dose sulfasalazine in a case of pyodermatitispyostomatitis vegetans. J Am Acad Dermatol 82:149-150.

8. Alfurayh N, Alhumidi A, Alkeraye S (2019) Pyodermatitis vegetans responding to rifampicin and clindamycin. JAAD Case Rep 5: 1078-1080.

9. Bertlich I, Gauss A, Schäkel K, Enk A, Hoffmann JHO (2019) Pyodermatitispyostomatitis vegetans with histological and immunohistological aspects of autoimmune blistering disease treated with infliximab. J Dtsch Dermatol Ges 17: 540-542.

10. Kawahira H, Higashi Y, Matsuoka A, Fujii K, Ishii N, et al. (2017) Pyodermatitis 
Citation: Tallman R, Beatty C, Ghareeb E, Gayam S, Zinn Z. Pyodermatitis-Pyostomatitis Vegetans: A Cutaneous Clue for Crohn's Disease. J Clin Investigat Dermatol. 2021;9(2): 4

ISSN: $2373-1044$

vegetans with antibodies to bullous pemphigoid antigen 180. J Dermatol 44 1417-1418.

11. Carvalho S, Sanches M, Alves R, Selores M (2016) Pyodermatitis vegetans of the vulva Dermatol Online 22: 13030.

12. Uzunçakmak TK, Akdeniz N, Karadağ AS, Çobanoğlu B (2015). Pyodermatitis vegetans after total colectomy. Indian Dermatol Online 6: 9-11.

13. Stingeni L, Tramontana M, Bassotti G, Bianchi L, Lisi P (2015) Pyodermatitis- pyostomatitis vegetans and antibullous pemphigoid antigen autoantibodies: a casual association $\mathrm{Br} \mathrm{J}$ Dermatol 172: 811-833.

14. Bens G, Laharie D, Beylot-Barry M, Vergier B, Noblesse I, et al. (2003) Successful treatment with infliximab and methotrexate of pyostomatitis vegetans associated with Crohn's disease. Br J Dermatol 149: 181-184.

15. Chateau T, Bonovas S, Le Berre C, Mathieu N, Danese S, (2019) Vedolizumab Treatment in Extra-Intestinal Manifestations in Inflammatory Bowel Disease: A Systematic Review. J Crohns Colitis 13: 1569-1577. 